\title{
Primary Testicular Failure
}

National Cancer Institute

\section{Source}

National Cancer Institute. Primary Testicular Failure. NCI Thesaurus. Code C131195.

Testicular failure due to a condition directly affecting the testes. 